\title{
SOME HERBAL MEDICINAL PRODUCTS AS A SOURCE OF PROMISING NATURAL PESTICIDES \\ Doaa S. $M^{1}$ and El-Sebae, A. ${ }^{1}$
}

Dept. of Environmental Protection, Faculty of Environ. Agri. Sc., El-Arish, Suez Canal

University, Egypt.

\begin{abstract}
Sitophilus granarius L. (Coleoptera: Curculionidae), the granary weevil, is a major stored product pest in many countries and specially in Egypt, causing tremendous losses estimated by $10-15 \%$. The present study was aimed to assess the impact of eleven essential oils from : Lavender oil (Lavandula angustifolia Mill), Rosemary oil (Rosmarinus officinalis L.), Garlic oil (Allium sativum L.), Soybean oil (Glycine max L. Merr), Sesame oil (Sesamum indicum L.), Cardamom oil (Elettaria cardamomum L. Maton), Castor oil (Ricinus communis L.), Camphor oil (Cinnamomum camphora L.), Olive oil (Olea europaea L.), Bitter almond oil (Prunus amygdalus B.), Coconut oil (Cocos nucifera L.) showing its toxicity and insecticidal activity against the adult granary weevil, Sitophilus granarius L. Tested plant oils were used with different concentrations and different exposure times (7,10,15 and 30 days). The results showed that the activities of tested oils were better at higher concentrations and higher durations and that was confirmed via the results of $\mathrm{LC}_{50}$ values obtained and variations between the different tested oils.
\end{abstract}

Key words: Sitophilus granarius L., plant oils, insecticidal activity, wheat.

\section{INTRODUCTION}

Stored-grain insect pests result in economic losses by infesting stored agricultural products. According to an estimate, the overall damage caused by stored-grain insect pests ranged between 10 to $40 \%$ of the annual worldwide loss (Matthews, 1993), ranging between 1.25 and 2.5 billion US dollars (Schöller et al., 2006). Sitophilus granarius (L.) (Coleoptera: Curculionidae), the granary weevil, is a major stored-product pest in regions of moderate climate. Furthermore, insect infestations in stored grain led to the production of heat and moisture, thus promoting fungal growth (Howe, 1951). The control of stored-product insect populations is primarily depends upon the continued applications of liquid and gaseous insecticides (White and Leesch, 1995; Ngamo et al., 2007b). Although, effective, their repeated use for several decades has disrupted the biological control systems by natural enemies and has led to outbreaks of insect pests, the widespread development of resistance, undesirable effects on non-target organisms, and environmental and human health concerns (Champ and Dyte, 1976; White and Leesch, 1995).

These problems have highlighted the need for the development of new types of selective insect-control alternatives with different modes of action. In this regard, many plant products have been evaluated for their insecticidal properties against different stored-grain pests (Kim et al., 2003; Cosimi et al., 2009). A number of plants produce essential oils that have been evaluated for their insecticidal properties against various insect pests (Shaaya et al., 1991; Kim et al., 2003; Ngamo et al., 2007a; Cosimi et al., 2009). 
Therefore, many efforts have been focused on plant-derived materials for potentially useful products as commercial insect-control agents.

The goal of this study was to assess the effect of applying some essential oils of: Lavender oil (Lavandula angustifolia Mill), Rosemary oil (Rosmarinus officinalis L.), Garlic oil (Allium sativum L.), Soybean oil (Glycine max L. Merr), Sesame oil (Sesamum indicum L.), Cardamom oil (Elettaria cardamomum L. Maton), Castor oil (Ricinus communis L.), Camphor oil (Cinnamomum camphora L.), Olive oil (Olea europaea L.), Bitter almond oil (Prunus amygdalus B.), Coconut oil (Cocos nucifera L.) as an effective tool in controlling the adult of Sitophilus granarius L., i.e: a natural promising protectants.

\section{MATERIALS AND METHODS}

\section{Tested plant oils:}

Essential oils obtained from local market, (El-Captain ${ }^{\circledR}$ company commercial producers of plant essential oils and aromatic substance) were used in this study as in Table (1).

\section{Insect culture and rearing conditions:}

The granary weevil, Sitophilus granarius L. was used for the present experiments.

A culture of a standard Laboratory strain of Sitophilus granarius L. was reared on the grains of wheat kept since 2009 in the laboratory of Environmental protection Department at $\left(28 \pm 2{ }^{\circ} \mathrm{C}\right.$ and $70 \pm 5 \%$ R.H.). Insects were reared in

Table (1): The Scientific name, Family, English name and Arabic name of tested plant oils:

\begin{tabular}{|c|c|c|c|}
\hline Scientific Name & Family & English Name & Arabic Name \\
\hline Lavandula angustifolia Mill & Lamiaceae & Lavender & اللافندر \\
\hline Rosmarinus officinalis $L$. & Lamiaceae & Rosemary & 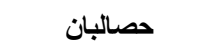 \\
\hline Allium sativum $L$. & Amaryllidaceae & Garlic & 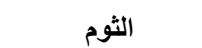 \\
\hline Glycine $\max$ L. Merr & Fabaceae & Soybean & فول الصويا \\
\hline Sesamum indicum $L$. & Pedaliacae & Sesame & 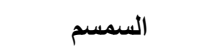 \\
\hline Elettaria cardamomum L. Maton & Zingiberaceae & Cardamom & الحبهان \\
\hline Ricinus communis $L$. & Acalypheae & Castor & 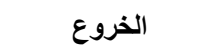 \\
\hline Cinnamomum camphora $L$. & Lauraceae & Camphor & الكافور \\
\hline Olea europaea $L$. & Oleaceae & Olive & الزيتون \\
\hline Prunus amygdalus $B$. & Rosaceae & Bitter almond & 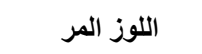 \\
\hline Cocos nucifera $L$. & Arecaceae & Coconut & جوز الهند \\
\hline
\end{tabular}


SINAI Journal of Applied Sciences (ISSN: 2314-6079), Vol.:(3), Is.:(3), Dec. 2014

plastic boxes $(15 \times 25 \mathrm{~cm})$ containing unifested wheat and covered with muslin which fixed tightly by a rubber band. Adults were removed and transferred each day: in this way, the newly emerged insects were homogeneous in the box. These adults were used in bioassays.

\section{Bioassay}

- Laboratory studies were conducted to investigate the insecticidal activity of tested plant oils at different concentrations against Sitophilus granarius (L.).

The insecticidal activity was determined by the test insect mortality at different exposure periods compared to the untreated control samples.

In these experiments, each of evaluated oils was prepared in a stock concentration of $(100 \mu 1$ oil /50 gram grains)(v/w) as follow :a dosage of $(100 \mu 1)$ of each tested oil was applied by using micropipette on the sample of $50 \mathrm{~g}$ sterilized wheat grains in petri dish and mixed well for coating the grains with that dosage of oil.

Also, in each bioassay trial a 100 adult insects of Granary Weevil ( Sitophilus granarius L. ), were collected and used in five replicates, in each one 20 adult insects. A series of concentrations of each tested oil were prepared. The percentage of mortality (\%) of adult insects was recorded after 7, 10, 15 and 30 days of exposure to the tested oil. The mortality percentages $(\%)$ were recorded to determine the $\mathrm{LC}_{50}$ values- Slope and confidence limits for each LDP- line by using the semi-log dosage - probit graphs according to (Finney, 1971).

\section{RESULTS}

Data of the insecticidal activity of the selected plant oils were presented in Table (2). In general, the mean mortality of the insect was observed at higher concentration and higher duration. The order of the efficacy of the insect mortality was as follows; after 7 days of exposure: Sesame and Camphor > Cardamom oil $>$ Soybean oil $>$ Olive oil $>$ Rosemary oil $>$ Bitter almond oil $>$ Garlic oil $>$ Lavender oil $>$ Castor oil $>$ Coconut oil.

In the case of 10 days after exposure: Sesame oil $>$ Cardamom and Camphor oils $>$ Soybean oil $>$ Olive oil $>$ Bitter almond oil $>$ Rosemary oil $>$ Garlic oil $>$ Lavender oil $>$ Castor oil $>$ Coconut oil . Also, after 15 days of exposure: Cardamom and Camphor $>$ Sesame oil $>$ Soybean oil $>$ Bitter almond and Olive oils $>$ Lavender oil $>$ Rosemary oil $>$ Garlic oil $>$ Castor oil $>$ Coconut oil. And 30 days of exposure: Sesame oil > Bitter almond, Cardamom and Camphor oil $>$ Soybean oil $>$ Olive oil $>$ Rosemary oil $>$ Castor oil $>$ Lavender oil $>$ Garlic oil $>$ Coconut oil.

\section{DISCUSSION}

The essential oils and their constituents have been shown to be a potent source of botanical pesticides (Huang et al., 2000). Also (Kostyukovsky et al., 2002) reported that a number of essential oils extracted from various spices and medicinal plants were found to be active against $S$. oryzae, $R$. dominica, $O$. surinamensis and T. castaneum.

And by throwing more light on that concept, where a number of these essential oils were extracted from spices, herbal and medicinal plants and applied against several stored product insects less detrimental to non-target organisms \& are readily biodegradable (Laznik et al., 2012).

(EL-Nahal et al., 1989) noticed that the period of exposure appeared to be the most important factor affecting the efficiency of these vapours rather than the dosage. (Laznik et al., 2012) proved that the activities of essential oils were better at higher concentrations than at lower ones. 
Table (2): Effect of different plant oils after different times of exposure against the adult stage of granary weevil, Sitophilus granarius L.

\begin{tabular}{|c|c|c|c|c|c|c|c|c|c|c|c|}
\hline \multicolumn{12}{|c|}{$\mathrm{LC}_{50}(\%)$ for Tested Oils } \\
\hline $\begin{array}{c}\text { Bioassay periods } \\
\text { (Days) }\end{array}$ & $\begin{array}{c}\text { Lavender } \\
\text { oil }\end{array}$ & $\begin{array}{c}\text { Rosemary } \\
\text { oil }\end{array}$ & $\begin{array}{c}\text { Garlic } \\
\text { oil }\end{array}$ & $\begin{array}{c}\text { Soy bean } \\
\text { oil }\end{array}$ & $\begin{array}{c}\text { Sesame } \\
\text { oil }\end{array}$ & $\begin{array}{c}\text { Cardamom } \\
\text { oil }\end{array}$ & $\begin{array}{c}\text { Castor } \\
\text { oil }\end{array}$ & $\begin{array}{c}\text { Camphor } \\
\text { oil }\end{array}$ & $\begin{array}{c}\text { Olive } \\
\text { oil }\end{array}$ & $\begin{array}{c}\text { Bitter } \\
\text { almond } \\
\text { oil }\end{array}$ & $\begin{array}{c}\text { Coconut } \\
\text { oil }\end{array}$ \\
\hline 7 & 0.202 & 0.121 & 0.175 & 0.040 & 0.022 & 0.026 & 0.537 & 0.022 & 0.064 & 0.128 & 1.678 \\
\hline 10 & 0.207 & 0.114 & 0.145 & 0.030 & 0.005 & 0.016 & 0.420 & 0.016 & 0.034 & 0.036 & 1.594 \\
\hline 15 & 0.072 & 0.101 & 0.137 & 0.015 & 0.008 & 0.007 & 0.270 & 0.007 & 0.028 & 0.028 & 1.556 \\
\hline 30 & 0.042 & 0.018 & 0.091 & 0.004 & 0.001 & 0.002 & 0.031 & 0.002 & 0.005 & 0.002 & 0.561 \\
\hline
\end{tabular}


SINAI Journal of Applied Sciences (ISSN: 2314-6079), Vol.:(3), Is.:(3), Dec. 2014

Commonly, we have to postulate in more and deep details and throwing more light on the main reasons responsible for different responses and attitudes of the tested botanical oils possessing a vast spectrum of properties, chiefly the insecticidal activity, Antimicrobials and .... etc.

Accordingly and besides all what mentioned before, it was noticed that there is a positive correlation between the toxicity of the oils and their taxonomic plant families reflecting different chemical constituents of these plant oils, which probably and ultimately responsible for all these different responses represented in different toxicity responses and levels. That attitude has a high degree of agreement with a lot of references (Calgar et al., 2007, Tripathi et al., 2009, Zapata and Smagghe 2010 and recently by Chaubey 2011 \& very recently Liu et al., 2013 and Chu et al., 2013).

And by going after more specifications, it was reported that these essential oils when tested against that pest and other related ones were affecting via inhalation, ingestion and absorption via its cuticle. That concept could be expected in that study and showing an accordance with the results recorded by (Anwar et al., 2005, Tripathi et al., 2009 and recently by Zapata and Smagghe 2010). So in other words we can say that it was the possible and expected mode of entry of these oils and explaining why these insects showed to be very sensitive for topical or contact application by these essential oils. These results in that study were in an agreement with that obtained by (Tapondjou et al., 2005, Iloba and Ekrakene 2006, Odeyem et al., 2008, Conti et al., 2010, Zapata and Smagghe 2010 and very recently by Chu et al., 2011).

Again by going after, the published and reported chemical structures of these oils in different references showing a high number of hydrocarbon's and other related compounds which mainly in the formal aliphatic or aromatic of terpenes, terpenoids (Tripathi et al., 2009).

Also phenols, alkaloids - sesquiterpenes and oxygenated monoterpenes were familiar and present in essential oils (Conti et al., 2010). So it is obviously and exactly that all these different structures of mainly and secondary compounds play a very clear and effective role in showing different biochemical responses and activities of these oils postulating the importance of these different phytochemicals and so reflecting a various \& diverse responses, (Conti et al., 2010).

So we can say that these previous observations in references were in an agreement with the different recorded results and achieving that concept of correlation between different oils - their chemical structures and different biochemical and toxicological activities.

Additionally it is well known that these oils mainly depends upon major volatile components they posses (Maciel et al., 2010).

Also these oils are lipophilic in its nature and permitting to show a degree of toxicity. Rather than these oils were anticipating different effects on metabolic processes-biochemical - physiological and behavioral changes towards the tested insects (Chaubey 2011).

That explanation could be expected in the recorded results, but it needs more studies to be sure of these facts.

So to fulfill the picture, it was reported 1 -stly about the mode of action of these oils is still not confirmed yet. But most appear to cause death of insects could be by suffocation (Khalezzaman and Chowdhury 2003). And by more specification (Tripathi et al., 2009) proved that route of action of oils was longely in the vapour phase via respiration causing an impairment for respiration. 


\section{Doaa Mohamed and El-Sebae}

That point of view also reported by (Zapata and Smagghe 2010). Recently (Singh 2012) showed that oil can be used preventively as well as curatively. Also the oil coating prevents gaseous exchanges. And more than the protective effect of oil may last for up to 3 months. That response was in an agreement with the recorded data in that study.

Rather than very recently (Grdiša, M. And Gršić 2013) proved that the major constituents of these botanical oils act as nerve toxins and contact poisons. Certainly, we have to pay attention to the need for more specific studies to can predict its mode of action and main targets affected. Again by throwing more light, since biological functions, normally are very selective processes, i.e: a group of chemical having certain and similar biological activities must show and reflect a feature of selectivity in its response (Horborne 1988).

That concept proved through that study offering a kind of physiological selectivity, so expecting and reflecting different modes of action of these plant oils, that criteria was confirmed very recently by (El-Araby 2014).

\section{CONCLUSION}

Plant oils can play an important role in stored-grain protection and reduce the need for, and risks associated with, the use of insecticides.

\section{REFERENCES}

Anwar, M.; Ashfaq, M.; Mansoor-ulHasan and Anjum, F. M. (2005): Efficacy of Azadirachta indica L. oil on bagging material against some insect pests of wheat stored in warehouses at Faisalabad, Pakistan Entomologist, Volume: 27, No. 1, Pages (89-94).

Caglar, O.; Calmasur, O.; Aslan, I. and Kaya, O. (2007): Insecticidal effect of essential oil of Origanum acutidens against several stored product pests, Fresenius Environmental Bulletin, Volume: 16, NUMB 11A, PP (1395-1400).

Champ, B. R. and Dyte, C. E. (1976): Report of the FAO global survey pesticide susceptibility of stored grain pests, FAO Plant Production Protection Series, Italy, Volume: 5, Pages (260-297).

Chaubey, M. K. (2011): Fumigant toxicity of essential oils against rice weevil Sitophilus oryzae L. (Coleoptera : Curculionidae), Journal of Biological Sciences, Volume: 11, Issue: 6, Pages (411-416).

Chu, S. S.; Liu, Q. Z.; Du, S. S. and Liu, Z. L. (2013): Chemical composition and insecticidal activity of the essential oil of the aerial parts of Ostericum grosseserratum (Maxim) Kitag (Umbelliferae), Tropical Journal of Pharmaceutical Research, Volume: 12, Issue: 1, Pages ( 99103).

Chu, S. S.; Liu, Q. Z.; Zhou, L.; Du, S. S. and Liu, Z. L. (2011): Chemical composition and toxic activity of essential oil of Caryopteris incana against Sitophilus zeamais, African Journal of Biotechnology Vol. 10 (42), pp. 8476-8480.

Conti, B.; Canale, A.; Cioni, P. L. and Flamini, G. (2010): Repellence of essential oils from tropical and Mediterranean Lamiaceae against Sitophilus zeamais, Bulletin of Insectology, Volume: 63, Issue: 2, Pages (197-202).

Cosimi, S.; Rossi, E.; Cioni, P. L. and Canale, A. (2009): Bioactivity and qualitative analysis of some essential oils from Mediterranean plants against stored-product pests: Evaluation of repellency against Sitophilus zeamais Motschulsky, Cryptolestes ferrugineus (Stephens) 
SINAI Journal of Applied Sciences (ISSN: 2314-6079), Vol.:(3), Is.:(3), Dec. 2014

and Tenebrio molitor (L.), Journal of Stored Products Research, Volume: 45, Issue: 2, Pages (125-132).

El-Araby, R. E-S (2014): Comparative study of biochemical and ecotoxicological effects of insecticides and potential alternatives on controling stored grain pests, Thesis.

El-Nahal, A. K. M.; Schmidt, G. H. and Risha, E. M. (1989): Vapours of Acorus calamus oil-A space treatment for stored- product insects, Journal of Stored Products Research, Volume: 25, Issue: 4, Pages (211- 216).

Entomol. Res., Volume: 4, Pages (125-134).

Finney, D. J. (1971): Probit Analysis, $3^{\text {rd }}$ edition. Cambridge University Press, Cambridge, UK.

Grdiša, M. And Gršić, K. (2013): Botanical Insecticides in Plan Protection, Agriculturae Conspectus Scientificus (acs), Volume: 78, No. 2, Pages (85-93).

Horborne, J. B. (1988): Recent advances in chemical ecology, Nat. Prod. Reports, Pages (323-344).

Howe, R. W. (1951): The movement of grain weevils through grain, Bull.

Huang, Y.; Lam, S. L. and Ho, S. H. (2000): Bioactivities of essential oil from Elletaria cardamomum (L.) Maton. to Sitophilus zeamais Motschulsky and Tribolium castaneum (Herbst), Journal of Stored Products Research ,Volume: 36, Pages (107-117).

Iloba, B. N.; Ekrakene, T. (2006): Comparative assessment on insecticidal effect of Azadirachta indica, Hyptis suaveolens and Ocimum gratissimum on Sitophilus zeamais and Callosobruchus maculates, Journal of Biological
Sciences, Volume: 6, Issue: 3, Pages (626-630).

Khalequzzaman, M. and Chowdhury, F. D. (2003): Evaluation of mixtures of plant oils as synergists for Pirimiphos- methyl in mixed formulations against Tribolium castaneum (Herbst), Journal of Biological Sciences, Volume: 3, Issue: 3, Pages ( 347- 359).

Kim, S-I.; Roh, J-Y.; Kim, D-H.; Lee, H-S. and Ahn, Y-J. (2003): Insecticidal activities of aromatic plant extracts and essential oils against Sitophilus oryzae and Callosobruchus chinensis, Journal of Stored Products Research,Volume 39, Issue: 3, Pages (293-303).

Kostyukovsky, M.; Ravid, U. and Shaaya, E. (2002): The potential use of plant volatiles for the control of stored product insects and quarantine pests in cut flowers, Proc. Int. Conf. on MAP, Eds. J. Bernáth et al., Acta Hort. 576, Pages (347-358).

Laznik, Ž.; Vidrih, M. and Trdan, S. (2012): Efficacy of four essential oils against Sitophilus granarius (L.) adults after short- term exposure, African Journal of Agricultural Research, Volume: 7, Issue: 21, Pages (3175-3181).

Liu, X. C.; Yang, K.; Wang, S. Y.; Wang, X. G.; Liu, Z. L. and Cheng, J. (2013): Composition and insecticidal activity of the essential oil of Pelargonium hortorum flowering aerial parts from China against two grain storage insects, Journal of Medicinal Plant Research, Volume: 7, Issue: 44, Pages (3263-3268).

Maciel, M. V.; Morais, S. M.; Bevilaqua, C. M. L.; Silva, R. A.; Barros, R. S.; Sousa, R. N.; Souse, L. C.; Brito, M. A. and Neto, S. M. A. (2010): Chemical composition of 
Eucalyptus spp. Essential oil and their insecticidal effects on Lutzomyia longipalpis, Vet. Parasitol, Volume: 167, Issue: 1, Pages (1- 7).

Matthews , G. A. (1993): Insecticide Application in Stores. In: Matthews et al. (eds) Application Technology for Crop Protection, CAB International, UK, Pages (305-315).

Ngamo, T. L. S.; Goudoum, A.; Ngassoum, M. B.; Mapongmetsem; Lognay, G.; Malaisse, F. and Hance, T. (2007a): Chronic toxicity of essential oils of 3 local aromatic plants towards Sitophilus zeamays Motsch (Coleoptera: Curculionidae), Afr. J. Agric. Res., Volume: 2, Issue: 4, Pages (164-167).

Ngamo, T. S. L.; Ngatanko, I.; Ngassoum, M. B.; Mapongmestsem, P. M. and Hance, T. (2007b): Persistance of insecticidal activities of crude essential oils of three aromatic plants towards four major stored products insect pest, Afr. J. Agric. Res., Volume: 2, Issue: 4, Pages (173-177).

Odeyem, O. O.; Masika, P. and Afolayan, A. J. (2008): Insecticidal activities of essential oil from the leaves of Mentha longifolia L. subsp. capensis against Sitophilus zeamais (Motschulsky)

(Coleoptera: Curculionidae), African Entomology, Volume: 16, Issue: 2, Pages (220225).

Schöller, M.; Flinn, P. W.; Grieshop, M. J. and Žd'árková, E. (2006): Biologicalcontrol of stored product pests. In: Heaps (ed) Insect management for food storage and processing, sec. ed. American Association of Cereal Chemists,
Pages (67-87).

Shaaya, E.; Ravid, U.; Paster, N.; Juven, B.; Zisman, U. and Pissarev, V. (1991): Fumigant toxicity of essential oils against four major stored-product insects, J. Chem. Ecol., Volume: 17, Pages (499-504).

Singh, A.; Khare, A. and Singh A. P. (2012): Use of vegetable oils as biopesticide in grain protection -A Review. 3:114, Journal of Biofertilizers \& Biopesticides, Volume: 3, Issue: 1, Pages (1-9).

Tapondjou, A. L.; Adler, C.; Fontem, D. A.; Bouda, H. and Reichmuth, C. (2005): Bioactivities of cymol and essential oils of Cupressus sempervirens and Eucalyptus saligna against Sitophilus zeamais Motschulsky and Tribolium confusum du Val, Journal of Stored Products Research, Volume: 41, Issue: 1, Pages (91-102).

Tripathi A. K.; Upadhyay S.; Bhuiyan M.; Bhattacharya P. R. (2009): A review on prospects of essential oils as biopesticide in insect-pest management, Journal of Pharmacognosy and Phytotherapy, Volume: 1, Issue: 5, Pages (52-63) .

White, N. D. G. and Leesch, J. G. (1995): Chemical control. In: Subramanyam et al. (eds) Integrated Management of Insects in Stored Products, Marcel Dekker, New York, Pages (171-213).

Zapata, N. and Smagghe, G. (2010): Repellency and toxicity of essential oils from the leaves and bark of Laurelia sempervirens and Drimys winteri against Tribolium castaneum, Industrial Crops and Products, Volume: 32 , Pages( 405-410). 


\section{الملخص العربي}

\section{بعض المنتجات العثبية الطبية كمصدر واعد للمبيدات الطبيعية} دعاء سامى محمد، على عبد الخالق السباعى

قسم حماية البيئة، كلية العلوم الزر اعية البيئية بالعريش، جامعة قناة السويس.

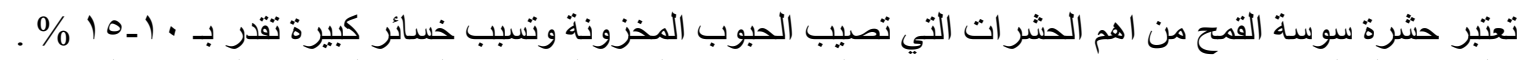

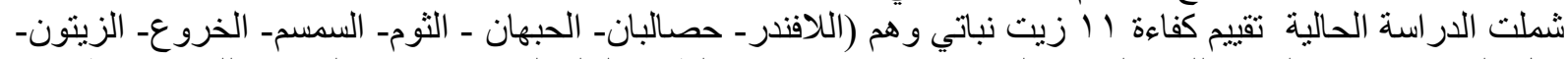

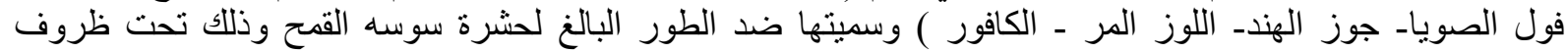

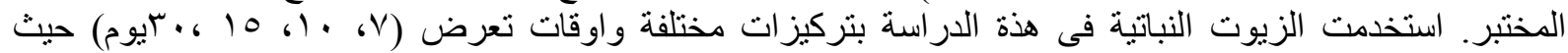

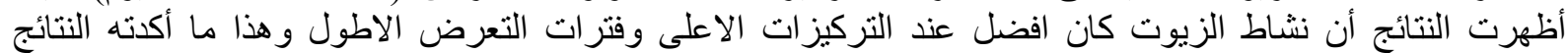

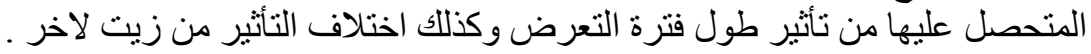

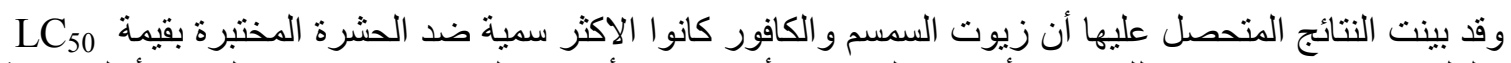

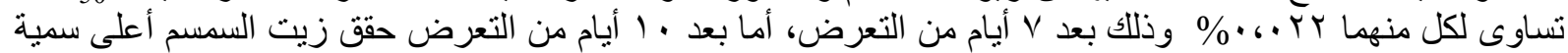
بقيمة

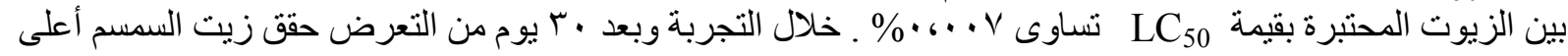

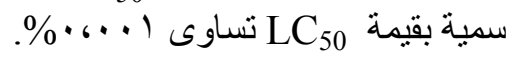
الكلمات الاسترشادية: سوسة القمح، المبيدات الطبيعية، الزيوت الطبيعية، العشبيات الطبية.

أستاذ بقسم الحشرات الاقتصادية، كلية العلوم الزراعية البيئية بالعريش، جامعة قناة السويس، مصر. أستاذ بقسم حماية البيئة، كلية الزراعة بالإسماعيلية، جامعة قناة السويس، مصر.

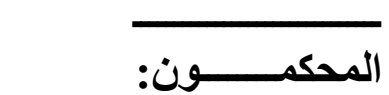

ا ـ أ.د/محمد نجيب البسيونى

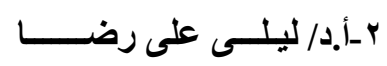


